\title{
Criteria for implementation of a tetrazolium test in canola seeds ${ }^{1}$
}

\author{
Mariana Faber Flores²*, Camila Ribeiro de Souza Grzybowski ${ }^{3}$ Kelly Pazolini ${ }^{4}$, \\ Jean Carlo Possenti ${ }^{5}$, Maristela Panobianco ${ }^{3}$
}

\begin{abstract}
Canola is an oilseed winter plant, constituting an alternative to crop rotation. It presents socioeconomic value for the production of vegetable oil for human consumption, biodiesel and animal food formulation. The evaluation of canola seed viability is routinely performed by germination test, which can be extended for up to 14 days if it is necessary to overcome dormancy. The objective of this study was to establish criteria for conducting a tetrazolium test in canola seeds, determining viability groups. Four lots of seed were used, placed between soaked paper to hydrate for 16 hours at $20^{\circ} \mathrm{C}$. In the coloration step, after preliminary tests, the following combinations of tetrazolium salt concentration, temperature and incubation period were tested: 0.5 and $1.0 \%$ at 30 ${ }^{\circ} \mathrm{C} ; 0.2,0.5$ and $1.0 \%$ at $40{ }^{\circ} \mathrm{C}$ for two, four and six hours. It was concluded that the evaluation of viability of canola seeds by the tetrazolium test is effective upon hydration of the seeds between papers for 16 hours at $20{ }^{\circ} \mathrm{C}$, coloration by immersion in $0.5 \%$ tetrazolium solution for six hours, at $40^{\circ} \mathrm{C}$ and two viability groups were established and illustrated.
\end{abstract}

Index terms: Brassica napus L. var oleifera, physiological quality, germination, dormancy.

\section{Critérios para execução do teste de tetrazólio em sementes de canola}

\begin{abstract}
RESUMO - A canola é uma planta oleaginosa de inverno, constituindo-se alternativa para a rotação de culturas. Apresenta valor socioeconômico pela produção de óleo vegetal para consumo humano, biodiesel e formulação de ração animal. A avaliação da viabilidade de sementes de canola é realizada rotineiramente pelo teste de germinação, que pode se estender por até 14 dias se houver a necessidade de superação da dormência. O objetivo do trabalho foi estabelecer critérios para condução do teste de tetrazólio em sementes de canola, determinando grupos de viabilidade. Utilizaram-se quatro lotes de sementes, colocadas para hidratar entre papel umedecido por 16 horas, a $20^{\circ} \mathrm{C}$. Na etapa de coloração, após testes preliminares, foram avaliadas as seguintes combinações de concentração do sal de tetrazólio, temperatura e período de incubação: 0,5 e $1,0 \%$ a $30{ }^{\circ} \mathrm{C} ; 0,2 ; 0,5$ e $1,0 \%$ a $40{ }^{\circ} \mathrm{C}$, durante duas, quatro e seis horas. Conclui-se que a avaliação da viabilidade das sementes de canola por meio do teste de tetrazólio é eficiente mediante hidratação das sementes entre papel por 16 horas a $20^{\circ} \mathrm{C}$, coloração por imersão em solução de tetrazólio a $0,5 \%$, durante seis horas, a $40{ }^{\circ} \mathrm{C}$, sendo estabelecidos e ilustrados dois grupos de viabilidade.
\end{abstract}

Termos para indexação: Brassica napus L. var oleifera, qualidade fisiológica, germinação, dormência.

\section{Introduction}

Canola (Brassica napus L. varoleifera) is an oilseed grown mainly in the south region of Brazil, and it is considered an option for the farmer to diversify winter crops, with prices similar to the soybeans and economical perspective for the production of oil for human consumption, besides being used as biodiesel (Tomm et al., 2009; Gazzoni et al., 2009), boosting the cultivation of the species.

The quality use of seeds provides fast emergency and

\footnotetext{
${ }^{1}$ Submitted on 08/14/2015. Accepted for publication on 10/13/2015.

${ }^{2}$ Universidade Federal do Paraná, 80060-000 - Curitiba, PR, Brasil.

${ }^{3}$ Departamento de Fitotecnia e Fitossanitarismo,UFPR, 80035-050 Curitiba, PR, Brasil.

${ }^{4}$ Departamento de Doenças de Plantas e Nematologia, USP/ESALQ, 13418-900 - Piracicaba, SP, Brasil.
}

uniformity of the seedlings in the field, enabling an appropriate establishment of the stand (Marcos-Filho, 2013). Therefore, methods that evaluate the physiological quality of the seeds in a faster and safer way must be researched, aiming at selecting the lots of superior physiological quality.

For canola seeds, the viability evaluation is usually done by the germination test, which can last for a period of up to 14 days (Brasil, 2009) when it is necessary to overcome dormancy. In that case, the tetrazolium test can be an alternative because it is not influenced by the dormancy

\footnotetext{
${ }^{5}$ Universidade Tecnológica Federal do Paraná, Caixa Postal 157, 85660-000 Dois Vizinhos, PR, Brasil.

*Corresponding author <marifaberflores@gmail.com>
} 
phenomenon and it provides faster results, once it is based on the activity of dehydrogenase enzymes. These enzymes are responsible for the respiratory reactions in the mitochondria from an oxi reduction reaction with chloride of 2,3,5triphenyltetrazolium (França-Neto, 1999), enabling the view of the live tissue (viable or not viable) from the one that remains dead (discolored) (Marcos-Filho, 2015).

Several authors have approached the appropriateness of the tetrazolium test methodology for seeds of different species such as Barbados nut (Pinto et al., 2009), castor beans (Gaspar-Oliveira et al., 2009), triticale (Souza et al., 2010), barley (Grzybowski et al., 2012), wheat (Carvalho et al., 2013), sunflower (Silva et al., 2013), sorghum (Carvalho et al., 2014), crambe (Rezende et al., 2015) and forage turnip (Nery et al., 2015).

For canola seeds, the recommendations found for the test, both in the Rules for Seed Testing - RAS (Brasil, 2009) and in the International Seed Testing Association - ISTA (ISTA, 2003), are general, covering only the Brassica spp. gender, lacking specifications for the Brassica napus species.

Therefore, ISTA (2003) recommends for Brassica spp. the pre-conditioning by immersion in water for 18 hours at $20{ }^{\circ} \mathrm{C}$ or for five hours at $30{ }^{\circ} \mathrm{C}$; it is indicated that the seeds be cut through a transverse incision in the external part of one of the cotyledons with later removal of the integument; the coloration should be done by immersion for 18 hours at $30{ }^{\circ} \mathrm{C}$ in a tetrazolium solution with concentration of $1.0 \%$. On the other hand, RAS (Brasil, 2009) recommends for this genre the pre-conditioning with immersion in water or between paper for 16 or 18 hours at $20^{\circ} \mathrm{C}$; the seed should be cut by a longitudinal incision through the integument and the cotyledons, or transverse incision in the external part of one of the cotyledons, with later removal of the integument; for coloration, the indication is for periods that range from three to 18 hours at $30{ }^{\circ} \mathrm{C}$, in the concentrations of 0.5 or $1.0 \%$. Therefore, it is seen a wide variation of procedures for the tetrazolium test for Brassica spp.

Considering that, the objective of this paper was to establish criteria for the execution of tetrazolium test in canola seeds, determining viability groups.

\section{Material and Methods}

The research was carried out in the period of March to July 2014, with four selected lots of canola seeds (Híbrido Hyola 433), with distinct levels of germination. Initially, the lots were homogenized through the mechanical method (centrifugal divider), based on the criteria from the Rules for Seed Testing (Brasil, 2009) and separated into four samples that formed the statistical repetitions. During an experimental period, the seeds were stored in Kraft paper bags, in a controlled environment with a temperature of $16 \pm 2{ }^{\circ} \mathrm{C}$ and $55 \%$ of relative air humidity.

To define the methodologies to be evaluated, initially, there were preliminary tests through different combinations of hydration, forms of preparation and coloration, according to the description on Table 1. Later on, the methodologies to be evaluated for the tetrazolium test (viability) in canola seeds were defined.

Table 1. Preliminary tests done to determine the preparation and coloration combinations of methodologies to be tested for the evaluation of canola seeds viability by the tetrazolium test.

\begin{tabular}{|c|c|c|c|c|c|}
\hline Pre-conditioning (h) & Preparation & $\begin{array}{c}\text { Hydration } \\
\text { temperature }\left({ }^{\circ} \mathrm{C}\right)\end{array}$ & $\begin{array}{l}\text { Tetrazolium } \\
\text { solution (\%) }\end{array}$ & $\begin{array}{l}\text { Coloration } \\
\text { (h) }\end{array}$ & $\begin{array}{c}\text { Coloration } \\
\text { temperature }\left({ }^{\circ} \mathrm{C}\right)\end{array}$ \\
\hline 16 & $\begin{array}{l}\text { Remove the } \\
\text { integument from the } \\
\text { seed }\end{array}$ & 20 & 0.075 and 0.1 & 2,4 and 6 & 40 \\
\hline 16 & \multirow{5}{*}{$\begin{array}{l}\text { Longitudinal incision } \\
\text { through the integument } \\
\text { and the cotyledons }\end{array}$} & 20 & 0.075 & 2,4 and 6 & 40 \\
\hline 16 & & 20 & 0.1 & 2,4 and 6 & 40 \\
\hline 16 & & 20 & 0.5 & 2,4 and 6 & 30 and 40 \\
\hline 16 & & 20 & 0.5 & 12 and 18 & 30 \\
\hline 16 & & 20 & 1.0 & 12 and 18 & 30 \\
\hline 16 & $\begin{array}{l}\text { Longitudinal incision } \\
\text { of the integument in } \\
\text { the external part of one } \\
\text { of the cotyledons, with } \\
\text { later removal of the } \\
\text { integument with slight } \\
\text { pressure. }\end{array}$ & 20 & 0.075 and 0.1 & 2,4 and 6 & 40 \\
\hline
\end{tabular}


The following determinations were done:

Water content: carried out by the oven method at $105 \pm 3{ }^{\circ} \mathrm{C}$ for 24 hours (Brasil, 2009), with two replicates of $5 \mathrm{~g}$.

Germination test: carried out with eight replicates of 50 seeds per lot, placed to germinate in plastic box $(11,0 \mathrm{x}$ $11,0 \times 3,5 \mathrm{~cm}$ ) on two blotter sheets of paper humidified with water in an amount equivalent to 2.5 times the mass of the dry substrate. Initially, there was a pre-cooling at $5{ }^{\circ} \mathrm{C}$ for a period of seven days; after that, the seeds were transferred to a Mangelsdorf germinator at $20^{\circ} \mathrm{C}$, with an evaluation of the percentage of normal seedlings at five days (Brasil, 2009).

For the tetrazolium test study, there were four replicates of 25 seeds per treatment, which were tested in the following combinations of pre-conditioning, preparation of the seeds and coloration:

Pre-conditioning - soaking in paper towel humidified with water in an amount equivalent to 2.5 times the mass of the substrate, for 16 hours at $20{ }^{\circ} \mathrm{C}$ (Brasil, 2009).

Preparation of the seeds - longitudinal incision in the integument (Brasil, 2009) with the help of a stainless steel blade and stereoscopic microscope, using tweezers to hold the seed at the moment of the cut (Figures 1a, 1b and 1c).

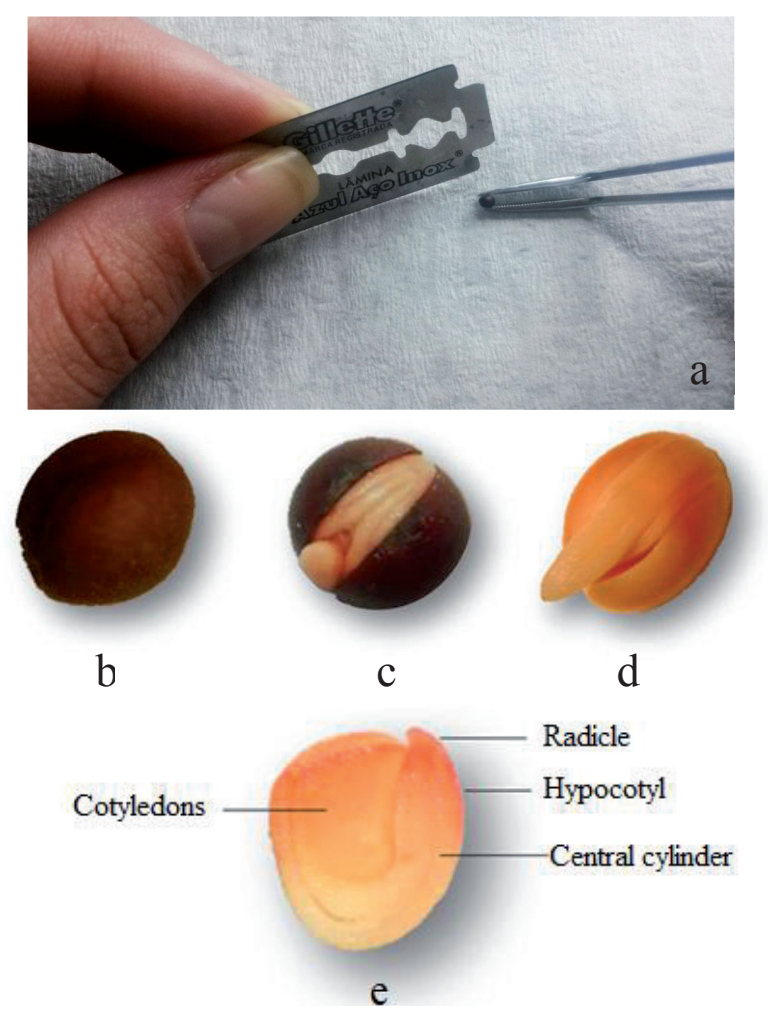

Figure 1. Canola seed: (a) longitudinal incision through integument and cotyledons; (b) intact seed; (c) seed after longitudinal incision in the integument; (d) embryo; (e) internal seed morphology.
Coloration - the seeds were place for coloration in a beaker glass $(100 \mathrm{~mL})$, in a dark environment for two, four and six hours, with concentrations of the chloride solution of 2, 3, 5 triphenyltetrazolium at 0.5 and $1.0 \%$ at $30{ }^{\circ} \mathrm{C}$ (Brasil, 2009) and at $0.2,0.5$ and $1.0 \%$ at $40{ }^{\circ} \mathrm{C}$.

When the ideal coloration was achieved, the seeds were taken from the chamber, washed in running water and kept submerged in water under refrigeration $\left(5-10^{\circ} \mathrm{C}\right)$ until the moment of the evaluation, for 12 hours at most.The evaluation was carried out with the help of a stereoscopic microscope, following the recommendations of the Rules for Seeds Testing (Brasil, 2009), observing mainly the vital area of the seed (embryonic axis) (Figure 1e) and the coloration intensity.The seeds were classified in two viability groups (viable and not viable), according to the coloration presented in the embryonic axis, calculating the percentage of viable seeds.

The experimental design was entirely randomized, with four replicates, and the averages were compared by the Tukey test at $5 \%$ probability. The seeds viability was also evaluated through the Spearman correlation between the average values of the tetrazolium test and the germination test.

\section{Results and Discussion}

The initial water content of the seeds lots (Table 2) presented similar values, crucial condition for the execution of the experiments, standardization of the evaluations and the obtaining of consistent results (Marcos-Filho, 2015). The results of the germination test (Table 2) indicated a separation into two groups regarding quality, that is, lots 1 and 2 were classified as superior physiologic quality and lots 3 and 4 as lower quality.

Table 2. Average data of the water content and initial germination of four lots of canola seeds.

\begin{tabular}{ccc}
\hline Lot & Water content (\%) & Germination (\%) \\
\hline 1 & 6.3 & $97 \mathrm{a}$ \\
2 & 6.4 & $97 \mathrm{a}$ \\
3 & 6.2 & $81 \mathrm{~b}$ \\
4 & 6.1 & $80 \mathrm{~b}$ \\
\hline C.V.(\%) & - & 3.38 \\
\hline
\end{tabular}

Means followed by the same letter in the column do not differ from each other by the Tukey test, at $5 \%$ probability.

Table 1 shows the preliminary tests carried out for the definition of the combinations of more efficient methodologies to be tested in this paper. It was observed that, for the preparation of the seeds, the methodologies that recommend the removal of the integument make the seed handling difficult because of its reduced size and jelly-like aspect. Considering 
the above, the preparation from the longitudinal incision through the integument and the cotyledons was the one that best adapted to the species.

Regarding coloration, the tetrazolium solution concentrations of 0.075 and $0.1 \%$ were not efficient because they presented weak coloration of the seeds regardless of the coloration time and the type of preparation. When the seeds were exposed to coloration of 12 and 18 hours, they presented excessive pigmentation, so it was not possible the correct visualization of the damage caused in the region of the embryo axis; thus, such methodologies were excluded from the paper.

The results of the tetrazolium test carried out with preconditioning between papers, with coloration by immersion at $30{ }^{\circ} \mathrm{C}$, during six hours, in solutions of tetrazolium at 0.5 and $1.0 \%$ (Table 3), procedure indicated in the RAS (Brasil, 2009). It can be observed that none of the combinations presented allowed us to classify the lots similarly to the germination test (Table 2). Probably the combination of time, temperature and solution concentration were not enough for the perfect coloration of the seeds. Silva et al. (2013) observed that, depending on the combination used for the incubation of the sunflower embryos in the tetrazolium test, there was less precision to distinguish the coloration of the tissues.

The coloration by immersion at $40{ }^{\circ} \mathrm{C}$, with $0.2 \%$ concentration, was not efficient either for the execution of the tetrazolium test in any of the coloration periods tested. In the concentration of $0.5 \%$ (Table 4 ), the four-hour coloration period separated the lots according to what was obtained from the germination test (Table 2), but the visualization of the embryo tissues was made difficult because the coloration pattern was not uniform.
The combination of coloration and tetrazolium solution at $0.5 \%$ for a period of six hours and $1.0 \%$ for two hours (Table 4) allowed us to rank the lots similarly to the germination test (Table 2), classifying lots 1 and 2 as having superior quality and lots 3 and 4 as worse performance. However, the treatment that enabled a better visualization and identification of the damage in the seeds tissues was with the use of the concentration of $0.5 \%$ for six hours, agreeing with the result obtained in the Spearman correlation, that is, maximum correlation for this treatment.

Table 3. Viability of canola seeds by the tetrazolium test, with pre-conditioning between papers, 6-hour coloration period, with tetrazolium solution in concentrations of 0.5 and $1.0 \%$, at $30{ }^{\circ} \mathrm{C}$.

\begin{tabular}{|c|c|c|}
\hline \multirow{5}{*}{ Lot } & \multicolumn{2}{|c|}{ Pre-conditioning between papers $(16 \mathrm{~h})$} \\
\hline & \multicolumn{2}{|c|}{ Coloration by immersion $\left(30^{\circ} \mathrm{C}\right)$} \\
\hline & \multicolumn{2}{|c|}{$6 \mathrm{~h}$} \\
\hline & \multicolumn{2}{|c|}{ Concentrations of the tetrazolium solution } \\
\hline & $0.5 \%$ & $1.0 \%$ \\
\hline & \multicolumn{2}{|c|}{$\ldots \% \ldots$} \\
\hline 1 & $82 b$ & $81 \mathrm{a}$ \\
\hline 2 & $84 \mathrm{a}$ & $79 b$ \\
\hline 3 & $84 \mathrm{a}$ & $81 \mathrm{a}$ \\
\hline 4 & $83 \mathrm{ab}$ & $78 \mathrm{~b}$ \\
\hline C.V. $(\%)$ & 1.19 & 0.77 \\
\hline${ }^{1}$ Spearman & $0.055^{\mathrm{ns}}$ & $0.5^{\mathrm{ns}}$ \\
\hline
\end{tabular}

Means followed by the same letter in the column do not differ from each other by the Tukey test, at $5 \%$ probability.

${ }^{1}$ Correlation coefficient of Spearman $(\rho)$ between the average data obtained in the germination and tetrazolium tests of four lots of canola seeds.

${ }^{\mathrm{n}}$ Non-significant by the $\mathrm{T}$ test.

Table 4. Viability of canola seeds by the tetrazolium test, with pre-conditioning between papers, under different periods of coloration, in tetrazolium solution with three concentrations $(0.2,0.5$ and $1.0 \%)$, at $40{ }^{\circ} \mathrm{C}$.

\begin{tabular}{|c|c|c|c|c|c|c|c|c|c|}
\hline \multirow{5}{*}{ Lot } & \multicolumn{9}{|c|}{ Pre-conditioning between papers $(16 \mathrm{~h})$} \\
\hline & \multicolumn{9}{|c|}{ Concentrations of the tetrazolium solution } \\
\hline & \multicolumn{3}{|c|}{$0.2 \%$} & \multicolumn{3}{|c|}{$0.5 \%$} & \multicolumn{3}{|c|}{$1.0 \%$} \\
\hline & \multicolumn{9}{|c|}{ Coloration by immersion $\left(40^{\circ} \mathrm{C}\right)$} \\
\hline & $2 \mathrm{~h}$ & $4 \mathrm{~h}$ & $6 \mathrm{~h}$ & $2 \mathrm{~h}$ & $4 \mathrm{~h}$ & $6 \mathrm{~h}$ & $2 \mathrm{~h}$ & $4 \mathrm{~h}$ & $6 \mathrm{~h}$ \\
\hline \multicolumn{10}{|c|}{$\%$} \\
\hline 1 & $89 \mathrm{a}$ & $89 \mathrm{a}$ & $87 \mathrm{~b}$ & $90 \mathrm{a}$ & $85 \mathrm{ab}$ & $88 \mathrm{a}$ & $85 \mathrm{a}$ & $80 \mathrm{~b}$ & $76 \mathrm{a}$ \\
\hline 2 & $88 \mathrm{a}$ & $88 \mathrm{~b}$ & $87 \mathrm{~b}$ & $87 \mathrm{~b}$ & $87 \mathrm{a}$ & $88 \mathrm{a}$ & $86 a$ & $80 \mathrm{~b}$ & $77 \mathrm{a}$ \\
\hline 3 & $88 \mathrm{a}$ & $87 \mathrm{~b}$ & $87 \mathrm{~b}$ & $87 \mathrm{~b}$ & $84 \mathrm{~b}$ & $79 b$ & $77 \mathrm{~b}$ & $81 \mathrm{a}$ & $76 \mathrm{a}$ \\
\hline 4 & $87 a$ & $88 \mathrm{ab}$ & $89 a$ & $89 a$ & $83 b$ & $78 b$ & $78 \mathrm{~b}$ & $80 \mathrm{~b}$ & $75 a$ \\
\hline C.V. $(\%)$ & 0.86 & 0.78 & 0.57 & 0.78 & 1.59 & 0.59 & 1.37 & 0.44 & 0.8 \\
\hline${ }^{I}$ Spearman & $0.83^{\text {ns }}$ & $0.5^{\mathrm{ns}}$ & $-0.81^{\mathrm{ns}}$ & $0.055^{\mathrm{ns}}$ & $0.94 *$ & $1 *$ & $0.73^{\mathrm{ns}}$ & $-0.27^{\mathrm{ns}}$ & $0.83^{\mathrm{ns}}$ \\
\hline
\end{tabular}

Means followed by the same letter in the column do not differ from each other by the Tukey test at $5 \%$ probability.

${ }^{1}$ Correlation coefficient of Spearman $(\rho)$ between the average data obtained in the germination and tetrazolium tests of four lots of canola seeds.

* Significant at $5 \%$ probability by the T test.

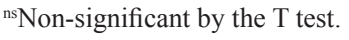


Although the treatment with concentration at $1.0 \%$ for two hours (Table 4) has enabled the ranking of the lots according to the germination test (Table 2), an intense coloration of the tissues was observed, which made interpretation very difficult. This fact was also pointed out by Gaspar-Oliveira et al. (2009) in castor bean seeds, Silva et al. (2013) in sunflower seeds, Rezende et al. (2015) in crambe seeds and Nery et al. (2015) in forage turnip seeds, when working with concentration of $1.0 \%$. It is worth highlighting that the correlation was not significant for this combination $(1.0 \% / 2 \mathrm{~h})$, fact which can be explained by the low degree of association between these variables.

The obtaining of favorable results for the evaluation of canola seeds viability employing the coloration methodology at $0.5 \%$ for six hours is relevant, once it enables a smaller coloration period than what is indicated in the Rules for Seed Testing (from six to 18 hours) and in ISTA (2003), which recommends 18 hours.

Such result contributed for a higher efficiency in the analysis of the seeds laboratories routine, enabling fast answers about the situation of the lots of seeds during their handling. In addition, it was possible to use a lower concentration than the one of $1.0 \%$ recommended by ISTA (2003), providing a cost reduction.

Some authors also identified the possibility of reduction in the concentration of tetrazolium solution for other species such as the crambe (Rezende et al., 2015), forage turnip (Nery et al., 2015), Araucaria angustifolia (Oliveira et al., 2014), sunflower (Silva et al., 2013), barley (Grzybowski et al., 2012), triticale (Souza et al., 2010), black oats (Souza et al., 2009) and castor beans (GasparOliveira et al., 2009).

In addition, the present research showed the influence of the temperature in the coloration of the seeds; when they were conditioned at $40{ }^{\circ} \mathrm{C}$ (Table 4), they presented an appropriate coloration for visualization and evaluation of the damages, fact not observed when the seeds were subjected to $30{ }^{\circ} \mathrm{C}$, according to the recommendation by RAS (Brasil, 2009). According to Marcos-Filho (2015), the use of higher incubation temperatures may favor the coloration of oilseeds, as observed with the canola seeds.

The size of the seeds was a difficulty observed, once the Brassica genre presents seeds considered small. However, the thickness and firmness characteristics of the integument of the canola seeds made the preparation of the seeds easier and allowed the cut, giving support to the seed. The procedure of removing the integument for the cut, recommended by RAS (Brasil, 2009), besides damaging the seeds, let them loose and with a jelly-like aspect (Figure 1d), not enabling the cut.

The viability classification groups were divided into viable seeds (a, b, c, d, e) and not viable (f, g, h, i, j, k, l, m, n, o)
(Figure 2). Thereby, the ones that belong to the alive and viable classification are those with well-developed embryo structures, intact and which are pink to light red (a, b, c, d, e); the alive and not viable ones are those which present intense red coloration in the embryo, affecting the central cylinder region, and the bad-developed embryo structures with intense-red coloration, characterizing deteriorated seed (f, g, h, i, j, k, o); the dead and not viable ones are those with more than half of the cotyledons area and/or hypocotyl-radicle axis without coloration, since there was no tetrazolium salt reduction $(1, \mathrm{~m}, \mathrm{n})$.

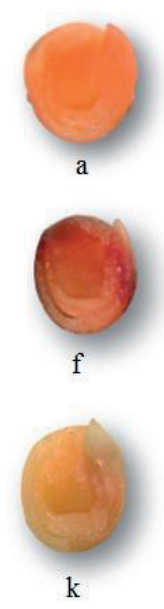

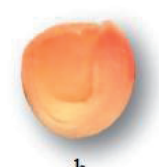

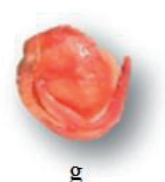

$\mathrm{g}$

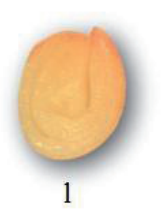

c
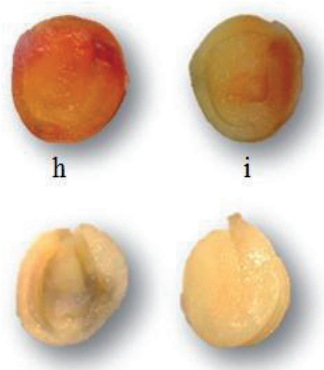

m
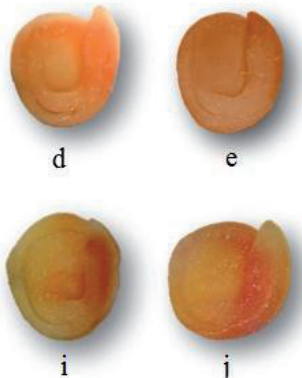

e
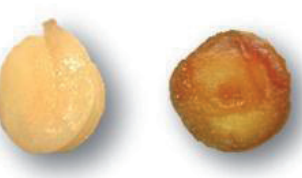

Figure 2. Tetrazolium test in canola seeds: group of viable seeds (a, b, c, d, e) and group of not viable seeds (f, $\mathrm{g}, \mathrm{h}, \mathrm{i}, \mathrm{j}, \mathrm{k}, \mathrm{l}, \mathrm{m}, \mathrm{n}, \mathrm{o})$.

\section{Conclusions}

The viability of the canola seeds evaluation by the tetrazolium test is efficient upon hydration of the seeds between papers for 16 hours at $20^{\circ} \mathrm{C}$, coloration at $40{ }^{\circ} \mathrm{C}$ by immersion in tetrazolium solution at $0.5 \%$ for six hours.

Two viability groups of the seeds were established and illustrated.

\section{Acknowledgments}

We thank to CAPES and $\mathrm{CNPq}$ for the granting of scholarships.

\section{References}

BRASIL. Ministério da Agricultura, Pecuária e Abastecimento. Regras para análise de sementes. Ministério da Agricultura, Pecuária e Abastecimento. Secretaria de Defesa Agropecuária. Brasília: MAPA/ACS, 2009. 395p. http:// www.agricultura.gov.br/arq_editor/file/2946_regras_analise_sementes.pdf 
CARVALHO, T.C.; KRZYZANOWSKI, F.C.; OHLSON, O.C.; PANOBIANCO, M. Tetrazolium test adjustment for wheat seeds. Journal of Seed Science, v.35, n.3, p.361-367, 2013. http://www.scielo.br/pdf/jss/ v35n3/13.pdf

CARVALHO, T.C.; GRZYBOWSKI, C.R.S.; OHLSON, O.C.; PANOBIANCO, M. Adaptation of the tetrazolium test method for estimating the viability of sorghum seeds. Journal of Seed Science, v.36, n.2, p.246-252, 2014. http://www.scielo.br/pdf/jss/v36n2/v36n2a14.pdf

FRANÇA-NETO, J.B. Teste de tetrazólio para determinação do vigor de sementes. In: KRZYZANOWSKI, F.C., VIEIRA, R.D., FRANÇA-NETO, J.B. (Ed.). Vigor de sementes: conceitos e testes. Londrina: ABRATES, 1999. cap.8, p.1-7.

GASPAR-OLIVEIRA, C.M.; MARTINS, C.C.; NAKAGAWA, J. Concentração da solução de tetrazólio e período de coloração do teste para sementes de mamoneira. Revista Brasileira de Sementes, v.31, n.3, p.038047, 2009. http://www.scielo.br/pdf/rbs/v31n3/a04v31n3.pdf

GAZZONI, D.L.; BORGES，J.L.B.; ÁVILA，M.T.; FELICI，P.H.N.; RALISCH, R. Balanço energético da cultura da canola para a produção de biodiesel. Espaço energia, número II, 2009. http://www.espacoenergia.com. br/edicoes/11/EE011-04.pdf

GRZYBOWSKI, C.R.S.; OHLSON, O.C.; SILVA, R.C.; PANOBIANCO, M. Viability of barley seeds by the tetrazolium test. Revista Brasileira de Sementes, v.34, p.47-54, 2012. http://www.scielo.br/pdf/rbs/v34n1/a06v34n1.pdf

ISTA. International Seed Testing Association -. In: ISTA Working Sheets on Tetrazolium Testing. Bassersdorf: ISTA, v.1, 2003.171p.

MARCOS-FILHO, J. Fisiologia de sementes de plantas cultivadas. 2.ed. Londrina: ABRATES, 2015. 660p

MARCOS-FILHO, J. Importância do potencial fisiológico da semente de soja. Informativo ABRATES, v.23, p.21-24, 2013. http://www.abrates.org.br/ images/Informativo/v23_n1/02._Julio_Importancia_Fisiologia.pdf

NERY, M.C.; NERY, F.C.; PIRES, R.M.O. Tetrazolium test to evaluate the viability of oil radish seeds. Bioscience Journal, v.31, n.3, p.663$671,2015 . \quad \mathrm{http} / / / \mathrm{www}$. seer.ufu.br/index.php/biosciencejournal/article/ view/22527/16450
OLIVEIRA, L.M.; GOMES, J.P.; SOUZA, G.K.; NICOLETTI, M.F.; LIZ, T.O.; PIKART, T.G. Metodologia alternativa para o teste de tetrazólio em sementes de Araucaria angustifolia (Bertol.) Kuntze. Floresta e Ambiente, v.21, n.4, p.468474, 2014. http://www.scielo.br/pdf/floram/2014nahead/01.pdf

PINTO, T.L.F.; MARCOS-FILHO, J.; FORTI, V.A.; CARVALHO, C.; GOMES JUNIOR, F.G.J. Avaliação da viabilidade das sementes de pinhão manso pelos testes de tetrazólio e de raios X. Revista Brasileira de Sementes, v.31, n.2, p.195-201, 2009. http://www.scielo.br/pdf/rbs/v31n2/v31n2a23.pdf

REZENDE, R.G.; JESUS, L.L.; NERY, M.C.; ROCHA, A.S.; CRUZ, S.M.; ANDRADE, P.C.R.Teste de tetrazólio em sementes de crambe. Semina, v.36, n.4, p.2539-2544, 2015. http://www.uel.br/revistas/uel/index.php/ semagrarias/article/view/13453

SILVA, R.C.; GRZYBOWSKI, C.R.S.; FRANÇA-NETO, J.B.; PANOBIANCO, M. Adaptação do teste de tetrazólio para avaliação da viabilidade e do vigor de sementes de girassol. Pesquisa Agropecuária Brasileira, v.48, n.1, p.105-113, 2013. http://www.scielo.br/pdf/pab/ v48n1/14.pdf

SOUZA, C.R.; OHLSON, O.C.; PANOBIANCO, M. Viabilidade de sementes de aveia preta pelo teste de tetrazólio. Revista Brasileira de Sementes, v.31, n.3, p.57-62, 2009. http://www.scielo.br/pdf/rbs/v31n3/a06v31n3.pdf

SOUZA, C.R.; OHLSON, O.C.; GAVAZZA, M.I.A.; PANOBIANCO, M Tetrazolium test for evaluating triticale seed viability. Revista Brasileira de Sementes, v.32, n.3, p.163-169, 2010. http://www.scielo.br/pdf/rbs/v32n3/ v32n3a18.pdf

TOMM, G.O.; FERREIRA, P.E.P.; AGUIAR, J.L.P.; CASTRO, A.M.G.C.; LIMA, S.M.V.L.; MORI, C. Panorama atual e indicações para aumento de eficiência da produção de canola no Brasil. Documentos online ISSN 15186512, Embrapa Trigo, Dezembro, 2009. http://www.cnpt.embrapa.br/biblio/ do/p_do118.htm 